This is an author postprint of the article which is published in final

form at doi.wiley.com/10.1002/jid.1437 Journal of International Development

2008, vol. 20, issue 5, pages 628-640. Copyright (c) 2008 JohnWiley \& Sons, Ltd.

\title{
ASSESSING PROTECTIONISM AND SUBSIDIES IN AGRICULTURE - A GRAVITY APPROACH
}

\author{
CLAUDIO PAIVA \\ Martin V. Smith School of Business \& Economics, \\ California State University, Channel Islands, \\ Camarillo, CA 93012
}

\begin{abstract}
This paper provides the first comprehensive empirical analysis of agricultural trade using a gravity model. The data set covers bilateral trade in agricultural goods for 152 countries over the periods 1990-1993 and 1999-2002. The estimations support claims that protectionism and distortive subsidies to agriculture remain widespread among industrialised nations, which are shown to import fewer and export more agricultural products than expected given other economic, political and geographic determinants of trade. However, some developing regions which are often thought to be the main victims of industrial-country protectionism are also found to be relatively closed to agricultural trade.
\end{abstract}

Keywords: trade; agriculture; protectionism; empirical; gravity equations; subsidies JEL Classification Numbers: F13; F14; F15

\section{INTRODUCTION}

After being virtually neglected through decades of rapid trade liberalisation, agricultural policymarket access, domestic support and export subsidies-has become one of the most contentious topics in trade negotiations. In fact, the lack of progress in agriculture reform has led to several missed deadlines in the latest round of negotiations promoted by the World Trade Organisation (WTO), putting at risk the Doha Development Agenda (Cline, 2004; WTO, 2004). The controversial issues often oppose industrial countries, notably the United States and members of the European Union and developing nations, led by Brazil, India and China, with the latter group claiming that tariffs, nontariff barriers and subsidies give an unfair advantage to farmers in industrialised countries (Matthews, 2001).

This paper applies the well-established empirical tool of gravity equations to model an extensive data set of bilateral trade in agricultural products in order to characterise the pattern and investigate the determinants of agricultural trade in the world. Dummy variables are progressively and selectively added to the general model so as to compare the relative trade performances of particular groups of countries divided by regions, stage of development and trading blocks. In determining which groups of countries import relatively fewer or export relatively more agricultural products than predicted by the standard determinants of trade, the analysis provides an empirical check for the existence of protectionist practices and unfair advantages created by subsidies to production or export activities. This seems to be the first paper that provides a detailed and comprehensive empirical analysis of agricultural trade using gravity models.

As a preview of the main results, this paper finds that rich countries imported relatively fewer agricultural products than other countries and that this gap increased in the 1990s, which would be consistent with the claim that industrial nations keep domestic agricultural markets relatively closed. Moreover, rich countries which are part of NAFTA and the EU exported more agricultural products than other countries, perhaps reflecting the substantial amount of subsidies granted to farming activities. Nonetheless, areas of the globe such as Latin America and Africa, which are normally thought to be the victims of rich countries' protectionism and distortive agricultural policy, were also found to be relatively closed to agricultural trade in the period analysed. 
The remainder of this paper is structured as follows. Section II discusses some aspects of the process of trade liberalisation observed in the last few decades, with emphasis on the differences between trade in agricultural products versus other merchandise and between rich versus developing nations. Data description, model estimates and results are presented in Section III. The last section brings the concluding remarks.

\section{UNEVEN TRADE LIBERALISATION AND MARKET ACCESS}

Progress in liberalising trade in agricultural goods has been substantially more modest than in other sectors. Total world trade increased from an average of about US\$2 trillion a year in the period 1990-1992 to US\$6.2 trillion in the period 2000-2002, an increase of nearly 210 per cent (Table 1). Trade in agricultural goods increased by about 140 per cent during the same period of comparison. As a result, the share of agricultural goods in world trade dropped from about 10.3 per cent in the early 1990 s to 7.8 per cent in the early 2000 s. The lower dynamism in agricultural trade is even more evident over a longer time horizon: between 1950 and 2002, the volume of trade increased at an yearly average of 6.3 per cent ( 7.7 per cent for manufactures), while the volume of trade in agricultural goods grew at an yearly average of only 3.6 per cent.

A closer look at the evolution of trade in 1990-2002 seems to support one of the complaints of developing countries: not only the expansion of agricultural trade lagged behind growth in overall trade, but agricultural exports of less developed countries also grew considerably slower than agricultural exports of OECD and mainly EU members (Table 2). Moreover, imported agricultural products in OECD and EU countries come overwhelmingly from other industrial nations, a trend that was reinforced during the 1990s and is hard to reconcile with the expected pattern of comparative advantages. As a result, the only important gain in market share for agricultural exports of LDCs during the last decade was observed in other LDCs, which obviously offer a much smaller market. ${ }^{1}$

The pattern of tariffs in industrial countries also seems to corroborate the bias against agricultural trade and developing nations. Although the simple average of import tariffs applied by developed nations declined between 1990 and 2002, the structure of these tariffs weighted more heavily on exports of LDCs, notably on agricultural goods (Table 3). The weighted average of tariffs imposed by developed countries on LDCs exports increased from 5.4 per cent in 1990 to 8.9 per cent in 2002, reflecting mainly an increase in the agricultural tariffs from 3.3 per cent to 6.6 per cent. On the other hand, tariffs applied by developed nations on EU agricultural exports declined from 7.9 per cent in 1990 to 4.6 per cent in 2002.

Substantial amount of protectionism remains in developing countries as well (Anderson, 2003; Tokarick, 2003). Not only the tariffs imposed by LDCs are higher than those levied by developed nations, but the tariff structure in the former group also weighs more heavily on agricultural goods and on exports of other LDCs (Table 3). ${ }^{2}$ For instance, in 2002, the tariffs imposed by LDCs on agricultural products coming from the EU were, on average, 4 percentage points lower than those levied on products coming from other LDCs. This pattern, however, is not observed in larger developing economies. Data for the same year show that the tariffs imposed on agricultural products by Indonesia, the Philippines, thi e Russian Federation and Mercosur countries fall slightly more heavily on developed countries' exports than on LDCs exports.

Besides market access, different forms of subsidies given to farmers in industrialized countries have been another source of contention in recent trade negotiations (Dimaranan et al., 2003; Francois et al., 2003; WTO, 2004). Total agricultural support in OECD countries amounted to US\$318 billion or 1.2 per cent of GDP in 2002. Although this amount has declined from an average of 2 per cent of GDP in 1990-1992, it is still very significant, especially when compared to the size of developing economies where agriculture remains the main economic activity. Moreover, most of this support (about 70 per cent) is given through output payments or 
direct price support, being therefore highly distortional to production and trade. Among the immediate consequences, prices received by OECD farmers were estimated to be about 30 per cent higher than world prices (Ingco and Nash, 2004). ${ }^{3}$

\section{DATA AND EMPIRICAL MODELLING}

\subsection{The Gravity Model}

The main idea behind the gravity model is that trade flows between two countries would be directly related to the size of their economies and inversely related to the distance between them (analogously to gravity in physics, hence the name). While economic size would be a major determinant of the demand for and supply of the products traded, the negative impact of distance on trade flows can be viewed as resulting from higher transportation costs. Although economic size and geographic distance are consistently the most important variables to predict the magnitude of bilateral trade flows, gravity models have normally included other economic, political and geographic factors such as whether partner countries have a free-trade agreement, speak the same language, share a common border, are landlocked or had colonial ties in the past.

The great ability of these relatively simple and intuitive models to explain actual trade patterns has earned them a place among 'the most empirically successful in economics', as observed by Anderson and vanWincoop (2003) in a paper that also provides a discussion of the theoretical underpinnings of gravity models. The vast literature which uses gravity equations to investigate economic and geographical determinants of trade also includes papers by Frankel (1997), Levy and Paiva (1998), Frankel and Rose (2002), Taglioni (2002), Croce et al. (2004), Rose (2004), and Subramanian and Wei (2007).

The general strategy of this paper will follow that of Rose (2004), who estimated a set of gravity equations to determine if the WTO or its predecessor General Agreement on Tariffs and Trade (GATT) in fact had a positive impact on trade, as it is generally assumed. His strategy was 'to control for as many "natural" causes of trade as possible, and search for the effects of multilateral agreements in the residual' by adding dummy variables that indicate membership to the WTO/GATT. The coefficient estimates for these dummy variables suggest there has been only a small and statistically insignificant impact of these organisations on trade. Applying the same general approach but somewhat different model specifications, Subramanian and Wei (2007) provided a rebuttal to those findings and showed that the WTO/GATT do have a significant and positive impact on trade flows. Using a similar strategy, this paper will start from a standard gravity equation and progressively add dummy variables to check whether certain groups of countries, especially high-income countries, trade more or fewer agricultural products than predicted by the standard determinants of trade.

In the specification used here, a country's imports of agricultural products from a partner country depend on the size of the countries' respective economies, their land areas, the physical distance between them, the physical distance between the exporter and other potential markets (a measure of remoteness) and several dummy variables capturing additional economic, political and geographical characteristics which shall be discussed in detail below. All these variables are standard in the literature of gravity equations. Because this paper innovates in focusing exclusively on gravity modelling of agricultural trade, some variables with specific importance for agricultural activity are included among the main explanatory variables: each country's share of agriculture in GDP and rural population density. In accordance to arguments in Subramanian and Wei (2007) and Anderson and vanWincoop (2003), country fixed effects are added to the model to capture country characteristics not specifically controlled for by other variables. Since the data set covers data of two distinct periods, namely the average in 1990-1993 and the average over 1999-2002, a dummy variable denoting the 
observations in the latter period is also included. The equations estimated thus have the following general specification (in natural logarithms):

$M_{t}=$ Distance + Remoteness $+\mathrm{SGDP}_{t}+\mathrm{BGDP}_{t}+\mathrm{SPCGDP}_{t}+\mathrm{BPCGDP}_{t}+\mathrm{SAREA}^{-\mathrm{BAREA}+}$ $\mathrm{SRPD}_{t}+\mathrm{BRPD}_{t}+\mathrm{SSAGDP}_{t}+\mathrm{BSAGDP}_{t}+$ Landl + Border + Comlang + Comcol + Colony + Island + FTA + Comcur $+\varphi_{i}+\mathrm{D} 99+\mathrm{DI}+\mathrm{E}_{t}$

where $M_{t}$ denotes the real US dollar amount of agricultural products imported at time $t$; Distance and Remoteness are, respectively, the distance between the two trading countries and between the exporter and a GDP-weighted average of its main trading partners; $\operatorname{SGDP}_{t}\left(\mathrm{BGDP}_{t}\right)$ is the seller (buyer) country's real GDP at time $t$; SPCGDP SBPCGDP $_{t}$ ) is the seller (buyer) country's real per capita GDP at time $t$; SAREA (BAREA) is the seller's (buyer's) physical area; SRPD (BRPD) is the seller's (buyer's) rural population density; SSAGDP $t\left(\right.$ BSAGDP $\left._{t}\right)$ is the seller's (buyer's) share of agriculture in GDP at time $t$; Landl (Island) indicates whether two, one or none of the trading countries are landlocked (Islands); Border (Comlang, Comcur) indicates whether the two trading countries share a common border (language, currency); Comcol indicates whether the two countries were ever colonised by the same country; Colony indicates whether a country was ever a colony of the other country; FTA indicates if the two countries are part of a regional trade agreement; ${ }^{4} \varphi_{i}$ are import country fixed effects; D99 indicates whether the observation corresponds to the latter period covered by the data; and $E_{t}$ is an error term.

The symbol DI denotes a set of dummy variables which are of central interest for the current study: (1) the dummy variable Brich, denoting importing countries whose income per capita exceeds US $\$ 10$ 000, and the regional dummy variables AFR (for African countries), ASI (for Asian countries), LA (for Latin American countries), MED (for Middle Eastern countries) and EUR (for European countries that are not members of the European Union) allow for an assessment of whether these groups of countries import relatively more or less than predicted by the other determinants of trade, (2) the dummy variable BothRich, denoting agricultural trade flows between two countries whose per capita incomes exceed US\$10 000, allows for an assessment of whether rich countries trade more agricultural goods among themselves and (3) the dummy variables Susacan and Seu, indicating whether the seller country is the US or Canada (Susacan) or a member of the EU (Seu), allow for an assessment of whether industrial countries in the NAFTA and EU regions export more agricultural products than predicted by the other determinants of trade.

\subsection{The Data}

Information on the value of agricultural imports (as classified by the WTO) of 152 countries from their main trading partners during the period 1990-1993 and 1999-2002 was obtained from the World Integrated Trade Solution Database (WITS), which, in turn, compiles data produced by the United Nations and the WTO. ${ }^{5}$ The number of partners and available observations vary across countries. The series for GDP, GDP per capita, share of agriculture in GDP and rural population density were extracted from the World Development Indicators Database produced by the World Bank. Countries' areas were obtained from the World FactBook produced by the United States Central Intelligence Agency (CIA). Finally, distances between countries were estimated with the EARTH software available through the United States Department of Agriculture web page. The series were averaged over two distinct periods, namely 1990-1993 and 1999-2002, in order to smooth out possible instability of agricultural production (bad harvests, etc.). The final data set used in the estimation has 18200 observations. 


\subsection{Results}

All estimations were done through ordinary least squares (OLS) and the main results appear in Table 4. All parameter estimates in the first model (summarised in the first column) have the expected signs. Imports of agricultural products are negatively affected by the distance between the trading countries and positively affected by the size of their economies. The magnitudes of these coefficients are also in line with most estimates of the impact of distance and economic size on total merchandise trade that are found in the literature. Exporting country remoteness is found to have a positive effect on trade, as the greater the average distance of a country to other markets the more it is expected to sell to a particular partner. The amount a country imports of agricultural goods seems to be inversely related to its land area, probably reflecting intra-border transportation costs (the conventional interpretation in studies of total trade) and/or the greater availability of land for domestic agricultural production. The land area of the exporting country was not found to be significant in various specifications and was dropped from the estimation.

The estimates show that a higher share of agriculture in GDP is associated with higher exports of agricultural goods, as expected, and that higher rural population density tends to reduce agricultural exports, probably reflecting the fact that in countries with a large rural population, agricultural activity is less modern and more oriented towards subsistence rather than commercial purposes.

Most geopolitical and historical characteristics also show a similar impact on agricultural trade as they have on aggregate trade according to the existing literature. Hence, agricultural trade tends to be lower when countries are landlocked and higher when partners share a common border, a common language, when they had the same colonizing country or when one of the partners was colonised by the other. ${ }^{6}$ The impact of regional FTAs on agricultural trade is positive and similar to the impact they have on total merchandise trade as estimated in Rose (2004).

Model II adds the square of distance (DistanceSQ) to the basic specification. The term is significant and (marginally) improves the overall fit of the regression, suggesting it is important to consider nonlinear effects of distance on agricultural trade. The inclusion of this term reduces the estimated impact of Border on trade, but all other coefficients remain virtually unchanged.

Model III is augmented with the variable Brich, a dummy variable that indicates the importing countries with per capita income greater than US\$10 000. The square of buyers' and sellers' GDPs are also added to the specification (estimated coefficients omitted for simplicity) to control for possible nonlinear effects of economic size on imports of agricultural goods, including changes in domestic demand patterns brought about by economic development. ${ }^{7}$ The coefficient estimated for Brich suggests that agricultural imports by these countries are about 40 per cent lower than expected, possibly reflecting the relatively higher incidence of tariff and nontariff barriers to agricultural trade as often claimed by developing nations. This result is broadly in line with Subramanian and Wei (2007), who found that industrialised countries import about 75 per cent fewer agricultural goods than the average importer in their sample. ${ }^{8}$ Note that the methodologies used in these studies do not provide a direct test of whether lower imports are caused by tariffs and nontariff barriers (as they do not enter the empirical model directly), although that is the interpretation normally found in the literature since other determinants of trade and country-specific characteristics are controlled for in the model. ${ }^{9}$

In order to assess possible changes in the degree of agricultural sector protection during the 1990s in countries defined as 'rich', Model IV includes a dummy variable (BrichL) that indicates when the importing country is rich and trade takes place in the latter period covered by the sample (the average in 1999-2002). The estimated coefficient suggests that rich countries imported even fewer agricultural goods than predicted during the latter period, a finding that is 
compatible with the claim that protectionist practices in these countries may have increased or become more generalised in recent years.

Model V simultaneously includes the dummy variables Brich and BothRich. The positive and significant coefficient estimated for the variable BothRich suggests that besides importing fewer agricultural goods than predicted, rich countries tend to import a larger share of agricultural goods from other rich countries in detriment of developing nations. This empirical finding is consistent with the tariff structure described in the previous section in which industrial countries are found to impose higher average tariffs on agricultural products from LDCs.

Additional results from the estimations are reported in Table 5, where full model specifications are omitted for simplicity. Dummy variables indicating when the exporting country is an industrial country member of NAFTA (Susacan) or the European Union (Seu) were added to the basic specification and their coefficient estimates are reported in Column VI. The new specification indicates that these countries export substantially more agricultural goods (about 48 per cent more, on average) than would otherwise be expected given other economic and geopolitical characteristics, a finding that is compatible with the claim that farming subsidies and other incentives to agricultural activities in industrialized nations give these countries an unfair advantage in international commodity markets. ${ }^{10}$

The dummy variables Susacan and Seu were multiplied by the dummy variable identifying the latter sample period (1999-2002) to yield SusacanL and SeuL. These two new variables are included in Model VII. The coefficient estimates suggest that the level of 'overexporting' by the United States and Canada declined in the more recent period covered by the sample, which may be related to the recorded decrease in government support to agricultural activities. Although EU countries have also shown a reduction in official agricultural support, the coefficient estimated for SeuL was positive and significant, which may be explained by the decline in tariffs imposed on EU agricultural products (Table 3).

The estimation strategy is changed somewhat for subsequent models, with countryspecific fixed effects giving place to regional dummy variables. Model VIII shows that (1) African and Latin American countries tend to import fewer and that (b) Asian and Middle Eastern countries tend to import more agricultural products in comparison to other regions of the world and after controlling for the determinants of trade discussed above. ${ }^{11}$ The dummy for European countries did not reach minimum significance levels. The core coefficients estimated in Model I remained broadly unchanged in the models with regional dummy variables.

Finally, Models IX and X show that the use of regional dummy variables do not alter the main analysis surrounding the set of DI, which again suggests that rich countries import fewer and industrialised nations in the EU and NAFTA regions export more, agricultural goods than warranted by economic size, distance between trading partners and other geopolitical and cultural determinants of trade. These models also confirm that 'overexporting' by the United States and Canada decreased in the late 1990s, whereas it increased for countries in the EU.

\section{CONCLUDING REMARKS}

The expansion of trade in agricultural products has lagged behind the increase in merchandise trade observed in the world over the last few decades. Moreover, the expansion in agricultural trade seems to have benefited LDCs exporters relatively less than those in industrialised nations, mainly in the EU. Many developing nations have seen these and other developments as the consequences of a biased process of trade liberalisation that should be changed in the next rounds of WTO and regional trade talks. The results of this paper indicate that industrialised nations import fewer and export more agricultural products than expected; however, the data also show that many developing countries import less than expected given their economic size and other determinants of trade. 
Using gravity equations to model a comprehensive data set of bilateral trade in agricultural products, this paper shows that the main determinants of trade in a gravity framework-namely economic size and distance-have the same impact on agricultural trade as they have on total merchandise trade. The same is true for the variables capturing geopolitical and historical characteristics of the trading partners. As for additional variables specific to agricultural trade, the estimates indicate that a higher share of agriculture in GDP and a lower rural population density are associated with higher exports of agricultural products.

The econometric analysis also identifies groups of countries (divided alternatively by regions, stage of development and trading blocks) whose pattern of trade is compatible with protectionism in or subsidies to the agricultural sector. It is found that countries with per capita income greater than US $\$ 10000$ tend to import fewer agricultural products than expected after controlling for the main determinants of agricultural trade. Moreover, these countries tend to trade more with each other, probably reflecting lower tariffs and nontariff barriers imposed on industrial countries' agricultural exports, mainly those coming from the EU. Nonetheless, countries in Latin America and Africa, which are often considered to be among the main victims of industrialised nations' protectionism in agriculture, have also been found to import less than expected, suggesting they maintain important barriers to agricultural trade as well.

Finally, the estimates also show that industrialised countries in the NAFTA and EU regions export substantially more agricultural goods than would otherwise be expected, a finding that is compatible with the claim that farming subsidies and other incentives to agricultural activities in industrialised nations gives them an unfair advantage in international commodity markets. The degree of 'overexporting' by the US and Canada declined through the 1990s, perhaps reflecting a relative reduction in farming subsidies in these countries. On the other hand, the degree of 'overexporting' by EU countries increased in the same period despite a similar reduction in farming subsidies, which may be associated with the observed reduction in tariffs placed on agricultural products coming from the region.

\section{ACKNOWLEDGEMENTS}

The author thanks, without implication, Eric Clifton, Ling Hui Tan, Andrew Feltenstein, Gabriela Inchauste, Miguel Messmacher, and Irineu de Carvalho for helpful discussion and comments. Wolfgang Harten and Deanna Ford provided outstanding research assistance.

\section{REFERENCES}

Anderson K. 2003. Trade Liberalization, Agriculture, and Poverty in Low-Income Countries, WIDER Discussion Paper No. 2003/25 (World Institute for Development Economics Research,United Nations, NY).

Anderson JE, vanWincoop E. 2003. Gravity with gravitas: a solution to the border puzzle. American Economic Review 93(1): 170-192.

Cline WR. 2004. Trade Policy and Global Poverty. Institute for International Economics: Washington.

Croce E, Juan-Ramon VH, Zhu F. 2004. Performance of Western Hemisphere Trading Blocs: A Cost-Corrected Gravity Approach, IMF Working Paper 04/109 (International Monetary Fund, Washington).

Dimaranan B, Hertel T, Keeney R. 2003. OECD Domestic Support and Developing Countries, WIDER Discussion Paper No. 2003/32 (World Institute for Development Economics Research, United Nations, NY).

Frankel J. 1997. Regional Trading Blocs in the World Economic System. Institute for International Economics: Washington. 
Frankel J, Rose A. 2002. An estimate of the effect of common currencies on trade and income. The Quarterly Journal of Economics, 117(2): 437-466.

Ingco MD, Nash JD (eds). 2004. Agriculture and the WTO_Creating a Trading System For Development. World Bank: Washington.

Levy J, Paiva C. 1998. The External Sector: Some Key Forces at Work in Portugal: Selected Issues, IMF Staff Country Report No. 97/121 (International Monetary Fund, Washington).

Matthews A. 2001. Developing countries' position in WTO agricultural trade negotiations. Development Policy Review 20(1): 75-90.

Rose AK. 2004. Do we really know that theWTO increases trade? American Economic Review 94(1): 98-114.

Stevens C. 2003. Food trade and food policy in Sub-Saharan Africa: old myths and new challenges. Development Policy Review 21(5-6): 669-681.

Subramanian A, Wei S. 2007. The WTO promotes trade, strongly but unevenly. Journal of International Economics 72(1): 151-175.

Taglioni D. 2002. Exchange rate volatility as a barrier to trade: new methodologies and recent evidence. E' conomie Internationale 89-90: 227-259.

Tokarick S. 2003. Measuring the Impact of Distortions in Agricultural Trade in Partial and General Equilibrium, IMF Working Paper 03/110 (International Monetary Fund, Washington).

World Trade Organization. 2004. WTO Agriculture Negotiations: The Issues, and Where We Are Now (Geneva) Available via the Internet http://www.wto.org/english/tratop e/agric e/agric e.htm

Table 1. Total and agriculture trade in the world 1950-2002

\begin{tabular}{|c|c|c|c|c|c|c|}
\hline & 1950-1952 & 1960-1962 & 1970-1972 & 1980-1982 & 1990-1992 & 2000-2002 \\
\hline Total trade & 30.5 & 56.1 & 149.1 & 802.7 & 1997.4 & 6191.7 \\
\hline (in US\$ billion) & & & & & & \\
\hline $\begin{array}{l}\text { Average volume } \\
\text { growth in the decade (\%) }\end{array}$ & 7.1 & 9.0 & 5.9 & 3.7 & 5.8 & 4.4 \\
\hline $\begin{array}{l}\text { Agricultural trade } \\
\text { (in US\$ billion) }\end{array}$ & 11.7 & 15.0 & 26.6 & 106.0 & 205.6 & 487.0 \\
\hline $\begin{array}{l}\text { Average volume } \\
\text { growth in the decade (\%) }\end{array}$ & 4.8 & 4.2 & 3.1 & 2.1 & 3.6 & 3.3 \\
\hline $\begin{array}{l}\text { Share of agriculture } \\
\text { in total trade (\%) }\end{array}$ & 38.4 & 26.7 & 17.8 & 13.2 & 10.3 & 7.9 \\
\hline
\end{tabular}

Source: WTO and author's calculations 
Table 2. Evolution of world trade in selected country groups 1990-2002

\begin{tabular}{lccc}
\hline & $1990-1992$ & $2000-2002$ & \% change \\
\hline World imports & & & \\
Total goods & 1997.4 & 6191.7 & 210 \\
Agricultural goods & 205.6 & 487.0 & 137 \\
from OECD & 135.9 & 329.1 & 142 \\
of which EU & 70.1 & 188.0 & 168 \\
from LDCs & 2.6 & 5.9 & 126 \\
OECD imports & 1612.0 & 4732.3 & 194 \\
Total goods & 172.1 & 372.1 & 116 \\
Agricultural goods & 117.7 & 270.4 & 130 \\
from OECD & 64.4 & 167.1 & 160 \\
of which EU & 1.8 & 3.6 & 101 \\
from LDCs & & & \\
EU imports & 640.0 & 2224.0 & 248 \\
Total goods & 76.9 & 206.4 & 168 \\
Agricultural goods & 54.8 & 160.4 & 193 \\
from OECD & 48.3 & 136.0 & 182 \\
of which EU & 0.9 & 2.4 & 155 \\
from LDCs & & 18.10 & 309 \\
LDCs imports & 4.42 & 3.35 & 300 \\
Total goods & 0.84 & 1.46 & 262 \\
Agricultural goods & 0.41 & 0.84 & 450 \\
from OECD & 0.15 & 0.14 & 500 \\
of which EU & 0.02 & & \\
from LDCs & & & \\
\hline
\end{tabular}

${ }^{1}$ In billions of US dollars, unless otherwise noted.

Source: WTO and United Nations (Comtrade database).

Table 3. Evolution of import tariffs in selected country groups, 1990-2002

\begin{tabular}{|c|c|c|c|c|c|c|c|c|}
\hline & \multirow{2}{*}{\multicolumn{2}{|c|}{$\begin{array}{l}\text { Simple } \\
\text { average }\end{array}$}} & \multirow{2}{*}{\multicolumn{2}{|c|}{ Std. deviation }} & \multicolumn{4}{|c|}{ Weighted average } \\
\hline & & & & & \multicolumn{2}{|c|}{$\begin{array}{l}\text { Originated in } \\
\text { LDCs }\end{array}$} & \multicolumn{2}{|c|}{$\begin{array}{l}\text { Originated } \\
\text { in EU }\end{array}$} \\
\hline & 1990 & 2002 & 1990 & 2002 & 1990 & 2002 & 1990 & 2002 \\
\hline \multicolumn{9}{|l|}{ Developed countries } \\
\hline Total goods & 6.9 & 3.3 & 8.9 & 9.5 & 5.4 & 8.9 & 5.6 & 2.0 \\
\hline $\begin{array}{l}\text { Agricultural products } \\
\text { LDCs }^{1}\end{array}$ & 7.5 & 3.6 & 10.6 & 20.5 & 3.3 & 6.7 & 7.9 & 4.6 \\
\hline Total goods & 24.0 & 15.1 & 23.9 & 11.5 & 31.2 & 12.7 & 13.6 & 12.0 \\
\hline Agricultural products & 25.0 & 18.3 & 22.4 & 11.8 & 38.9 & 17.2 & 16.5 & 13.3 \\
\hline
\end{tabular}

${ }^{1}$ Data for 1990 refers to the group of Sub-Saharan countries.

Source: WTO and United Nations (Comtrade database). 
Table 4. Main econometric results

\begin{tabular}{|c|c|c|c|c|c|}
\hline & Model I & Model II & Model III & Model IV & Model V \\
\hline Distance & $-1.05(-40.0)$ & $-2.13(-8.3)$ & $-2.12(-8.2)$ & $-2.12(-8.2)$ & $-2.12(-8.3)$ \\
\hline Remoteness & $1.18(18.6)$ & $1.17(18.4)$ & $1.17(18.2)$ & $1.17(18.2)$ & $1.17(18.0)$ \\
\hline Sgdp & $0.81(77.4)$ & $0.81(77.4)$ & $0.82(40.7)$ & $0.81(40.6)$ & $0.81(40.3)$ \\
\hline Spcgdp & $0.25(9.9)$ & $0.25(9.8)$ & $0.24(9.7)$ & $0.24(9.5)$ & $0.23(9.0)$ \\
\hline Srpd & $-0.24(-15.6)$ & $-0.24(-15.5)$ & $-0.24(-15.5)$ & $-0.24(-15.5)$ & $-0.24(-15.4)$ \\
\hline Ssagdp & $0.34(9.8)$ & $0.35(9.8)$ & $0.34(9.7)$ & $0.34(9.4)$ & $0.34(9.5)$ \\
\hline Bgdp & 0.87 (12.5) & 0.87 (12.5) & $0.95(11.2)$ & 0.95 (11.2) & $0.95(11.2)$ \\
\hline Barea & $-0.16(-3.7)$ & $-0.16(-3.7)$ & $-0.21(-4.2)$ & $-0.21(-4.2)$ & $-0.21(-4.1)$ \\
\hline Bpcgdp & $0.04(0.5)$ & $0.04(0.4)$ & $0.11(1.2)$ & $0.14(1.5)$ & $0.11(1.2)$ \\
\hline Landl & $-0.37(-7.4)$ & $-0.37(-7.4)$ & $-0.37(-7.4)$ & $-0.36(-7.4)$ & $-0.37(-7.5)$ \\
\hline Island & $-0.22(-3.7)$ & $-0.24(-4.0)$ & $-0.23(-3.8)$ & $-0.23(-3.8)$ & $-0.23(-3.9)$ \\
\hline Border & $0.81(9.1)$ & $0.65(6.8)$ & $0.65(6.9)$ & $0.65(6.9)$ & $0.65(6.9)$ \\
\hline Comlang & $0.62(7.8)$ & $0.63(7.8)$ & $0.63(7.8)$ & $0.63(7.8)$ & $0.62(7.8)$ \\
\hline Comcol & 0.37 (4.2) & $0.36(4.1)$ & $0.36(4.1)$ & 0.36 (4.1) & 0.37 (4.2) \\
\hline Colony & $1.43(13.8)$ & $1.44(13.9)$ & $1.44(13.9)$ & $1.44(13.9)$ & $1.45(14.0)$ \\
\hline FTA & 1.15 (13.8) & $1.10(13.1)$ & $1.11(13.2)$ & $1.11(13.2)$ & 1.01 (11.1) \\
\hline DistanceSQ & & $0.07(4.2)$ & $0.07(4.1)$ & $0.07(4.1)$ & $0.07(4.2)$ \\
\hline Brich & & & $-0.51(-2.1)$ & $-0.43(-1.8)$ & $-0.55(-2.3)$ \\
\hline BrichL & & & & $-0.18(-3.2)$ & \\
\hline BothRich & & & & & $0.23(3.5)$ \\
\hline $\begin{array}{l}\text { Income squared } \\
\text { terms }\end{array}$ & No & No & Yes & Yes & Yes \\
\hline $\mathrm{R} 2$ & 0.585 & 0.586 & 0.586 & 0.586 & 0.586 \\
\hline Schwarz criterion & 1.5697 & 1.5705 & 1.5705 & 1.5705 & 1.5706 \\
\hline
\end{tabular}

Note: Numbers in parentheses are heteroscedasticity-consistent t-ratios; all specifications were estimated through OLS with country fixed effects.

Table 5. Additional econometric results

\begin{tabular}{lccccc}
\hline & Model VI & Model VII & Model VIII & Model IX & Model X \\
\hline Brich & $-0.52(-2.1)$ & $-0.42(-1.7)$ & & $-0.29(-4.4)$ & $-0.27(-4.1)$ \\
BrichL & & $-0.19(-3.3)$ & & $-0.10(-1.8)$ & $-0.10(-1.9)$ \\
Suscan & & & & \\
Seu & $0.39(3.9)$ & $0.49(4.3)$ & & & $0.55(4.7)$ \\
SuscanL & $0.46(8.1)$ & $0.38(5.5)$ & & & $0.37(5.4)$ \\
SeuL & & $-0.18(-1.5)$ & & & $-0.22(-1.7)$ \\
AFR & & $0.14(2.2)$ & & & $0.11(1.7)$ \\
ASI & & & $0.29(-4.3)$ & $-0.34(-4.9)$ & $-0.35(-5.2)$ \\
LA & & & $-0.74(-11.7)$ & $-0.84(-12.6)$ & $-0.84(-12.6)$ \\
MED & & & $0.57(5.5)$ & $0.46(4.4)$ & $0.45(4.3)$ \\
Income squared & Yes & Yes & No & Yes & Yes \\
terms & & & & No & \\
Country fixed effects & Yes & Yes & No & No & No \\
R2 & 0.587 & 0.587 & 0.567 & 0.568 & 0.569 \\
Schwarz criterion & 1.5688 & 1.5697 & 1.5554 & 1.5553 & 1.5547 \\
\hline
\end{tabular}

Note: All specifications were estimated through OLS and with DistanceSQ among the explanatory variables; this and other coefficient estimates were omitted for simplicity. 
APPENDIX

Countries covered by the data set

\begin{tabular}{|c|c|c|c|}
\hline Angola & Algeria & Kyrgyz Republic & Russia \\
\hline Albania & Ecuador & Cambodia & Rwanda \\
\hline Argentina & Egypt & Kiribati & Saudi Arabia \\
\hline Armenia & Spain & St. Kitts & Senegal \\
\hline Antigua and Barbuda & Estonia & Korea & Singapore \\
\hline Australia & Ethiopia & Lao PDR & Solomon Islands \\
\hline Austria & Finland & St. Lucia & Sierra Leone \\
\hline Azerbaijan & Fiji & Sri Lanka & El Salvador \\
\hline Burundi & France & Lithuania & Suriname \\
\hline Belgium & Gabon & Luxembourg & Slovak Republic \\
\hline Benin & United Kingdom & Latvia & Slovenia \\
\hline Burkina Faso & Georgia & Morocco & Sweden \\
\hline Bangladesh & Ghana & Moldova & Swaziland \\
\hline Bulgaria & Guinea & Madagascar & Seychelles \\
\hline Belarus & The Gambia & Mexico & Syria \\
\hline Belize & Guinea-Bissau & Macedonia & Chad \\
\hline Bolivia & Equatorial Guinea & Mali & Togo \\
\hline Brazil & Greece & Mongolia & Thailand \\
\hline Barbados & Grenada & Mozambique & Tajikistan \\
\hline Bhutan & Guatemala & Mauritania & Turkmenistan \\
\hline Botswana & Guyana & Mauritius & Tonga \\
\hline Central African Republic & P.R.: China-Hong Kong & $\begin{array}{l}\text { Malawi } \\
\text { Malaysia }\end{array}$ & $\begin{array}{l}\text { Trinidad and Tobago } \\
\text { Tunisia }\end{array}$ \\
\hline Canada & Honduras & Namibia & Turkey \\
\hline Switzerland & Croatia & Niger & Tanzania \\
\hline Chile & Haiti & Nigeria & Uganda \\
\hline China & Hungary & Nicaragua & Ukraine \\
\hline Cote d'Ivoir & Indonesia & Netherlands & Uruguay \\
\hline Cameroon & India & Norway & United States \\
\hline Colombia & Ireland & Nepal & Uzbekistan \\
\hline Comoros & Iran & New Zealand & Venezuela \\
\hline Cape Verde & Iceland & Pakistan & Vietnam \\
\hline Costa Rica & Israel & Peru & Vanuatu \\
\hline Cyprus & Italy & Philippines & Samoa \\
\hline Czech Republic & Jamaica & Papua New Guinea & Yemen \\
\hline Germany & Jordan & Poland & South Africa \\
\hline Dominica & Japan & Portugal & Zambia \\
\hline Denmark & Kazakhstan & Paraguay & \\
\hline Dominican Republic & Kenya & Romania & \\
\hline
\end{tabular}


${ }^{1}$ LDCs refer to the group of Least Developed Countries as defined by the WTO.

${ }^{2}$ Although data for the group of LDCs are not available for the early 1990s, a comparison using the group of Sub-Saharan countries (for which the 2002 data are very similar to LDCs as a whole) shows that the average of tariffs imposed on agricultural exports of LDCs declined by about 20 percentage points between 1990 and 2002,substantially narrowing the gap against tariffs levied on developed countries' agricultural exports.

${ }^{3}$ Although some types of price support also end up benefiting exporters in poor nations. See, for instance, Stevens (2003).

${ }^{4}$ The regional trade agreements considered here are Association of Southeast Asian Nations (ASEAN), North America Free Trade Agreement (NAFTA), the EU, Southern Cone Common Market (MERCOSUR), South Pacific Regional Trade and Economic Cooperation Agreement (SPARTECA), Caribbean Community and Common Market (CARICOM), Papua New Guinea and Australia Trade and Commercial Relations Agreement (PATCRA) and Central American Common Market (CACM).

${ }^{5} \mathrm{~A}$ list of all countries covered by this data set can be found in the appendix.

${ }^{6}$ The dummy variables Comcur and D99 failed to reach standard minimum significance levels and were omitted from the final specification.

${ }^{7}$ For instance, this term could account for richer countries spending a lower share of their income on (imported) food and other agricultural products.

${ }^{8}$ Although both studies cover similar time periods, Subramanian and Wei (2007) refer to industrialized countries per se and use a sample with only 4000 observations after discarding trade flows of less than US $\$ 500$ 000. Moreover, their estimates are obtained from a system of seemingly unrelated regressions (SUR) and a slightly different set of regressors since they address in the impact of WTO membership on agriculture and four other sectors.

${ }^{9}$ It would not be feasible to directly account for bilateral tariffs and all forms of non-tariff trade barriers in an empirical study with such high number of countries. More generally, the large number of (small) factors affecting trade between countries probably help explain the growing use of gravity models in empirical trade studies.

${ }^{10}$ Dummy variables indicating exports from Japan and from NAFTA as a whole (including Mexico) did not reach minimum significance levels when added to the basic model.

${ }^{11}$ The dummy for common currency was also included in this specification, but it was again found to be statistically non-significant. 